\title{
Rapid decline of an isolated population of the black grouse Tetrao tetrix: the crisis at the southern limit of the range
}

\author{
Michał Ciach ${ }^{1}$ \\ Received: 23 October 2014 / Revised: 22 April 2015 / Accepted: 25 April 2015 / Published online: 6 May 2015 \\ (C) The Author(s) 2015. This article is published with open access at Springerlink.com
}

\begin{abstract}
Over the last century, the numbers and range of black grouse Tetrao tetrix have declined dramatically over most of Europe. The Central-European population is at present divided into small, isolated subpopulations, and Orawa (Carpathians, Poland-Slovakia) was considered until recently to be the most abundant one in the region. In 2002, it was estimated at 146-152 males. Surveys conducted in 20112014 showed that only $30-40$ males were still present in this region. The total disappearance of leks (13 of 24 known leks have been abandoned) and the decline in overall numbers of males at existing leks (some leks were used by single males only) were recorded. In consequences, the number of lekking males decline by $76 \%$ between 2002 and 2014 . The nearest neighbour distance between active leks did not change, but the contraction of the total area used by the population (from $187.3 \mathrm{~km}^{2}$ in 2002 to $71.5 \mathrm{~km}^{2}$ in 2014) was recorded. The disappearance of leks was related to the size of the nearest peat bog; leks located close to small peat bogs were abandoned, while those located close to the larger ones remained active. Along with the decline in the numbers of lekking birds and the shrinkage of the range, a decrease in the size of wintering flocks was noted. This rapid fall over a short period of time in the number of black grouse and in the area used by the
\end{abstract}

Communicated by P. Acevedo

Electronic supplementary material The online version of this article (doi:10.1007/s10344-015-0923-7) contains supplementary material, which is available to authorized users.

Michał Ciach

michal.ciach@ur.krakow.pl

1 Department of Zoology and Wildlife Management, Forest Biodiversity Institute, Faculty of Forestry, Agricultural University of Kraków, 29 Listopada 46, 31-425 Kraków, Poland region's largest population is indicative of a real threat of extinction of isolated populations. Rapid extinction risk should be taken into consideration when planning conservation measures applicable to its entire range of distribution.

Keywords Black grouse $\cdot$ Tetrao tetrix $\cdot$ Leks $\cdot$ Population decline

\section{Introduction}

The distribution range of black grouse Tetrao tetrix has contracted dramatically over most of Europe in the past century, and there has been a corresponding fall in birds numbers (Storch 2007). Given the species' sedentary habits and its lack of long-distance movements, the drop in numbers and local extinctions have led to the fragmentation and isolation of discrete populations. In much of Europe, therefore, black grouse exhibits a low level of genetic variability, which is particularly apparent in small and isolated populations (Höglund et al. 2007).

Black grouse is one of the most rapidly disappearing bird species in Poland. In recent decades, the national population of this species has been in severe decline; between 1982-1983 and 2006-2007, the species has withdrawn from ca. $70 \%$ of its range (Kamieniarz 1997, 2008), and at present, the population is divided up into several isolated subpopulations. The Carpathian Mountains, and the Orawa region in particular, were until recently considered to hold one of the largest subpopulation of black grouse in Poland and Slovakia (Danko et al. 2002; Tomiałojć and Stawarczyk 2003).

The number of birds inhabiting Polish part of the Orawa region was estimated at 146-152 males in 2002 (Cichocki 2008), and on the Slovakian part, it was estimated at 65-75 males in 2004 (SDF 2012). However, this subpopulation, 
forming a southern limit of the species range (Hagemeijer and Blair 1997), is particularly vulnerable to negative trends. Black grouse population can decline very rapidly and become extinct within the space of a few years. In view of the ongoing decline in populations observed across much of Europe, a study was undertaken in 2011-2014 to assess the current numbers of the species in the Orawa region.

\section{Study area and methods}

The Orawa region, i.e. Orawa-Nowy Targ Basin $\left(49^{\circ} 26^{\prime} \mathrm{N}\right.$; $19^{\circ} 48^{\prime}$ E; Western Carpathians, S Poland-N Slovakia, Fig. 1) is an extensive basin of uniform landscape. Within the borders of Poland, it has an area of ca. $370 \mathrm{~km}^{2}$. The floor of the basin lies at an altitude of ca. $500-600 \mathrm{~m}$ and is surrounded by mountain ranges. The Orawa region is covered by the largest peat bog complex in the Carpathians. It consists of 15 parts and cover a total area of ca. 1300 ha (Lajczak 2013). In the vicinity of the raised bog domes, there are fens, roughly $1500 \mathrm{ha}$, and small patches of pine-spruce forests. Many of the open parts of the Orawa region are farmed extensively.
Typically, the habitats here are highly fragmented; meadows, pastureland, fallows and to a small extent arable land make up a diverse mosaic of open areas, crisscrossed by streams and drainage ditches, with scattered copses, roads and built-up areas.

A survey of lekking black grouse was carried out in the Orawa region in 2011-2014. From March to May (mainly in April), all the known leks were monitored from one to five times (except for 2013, when only selected leks were surveyed, mainly the largest ones). To prevent multiple counts of birds moving between leks, a group of observers simultaneously monitored adjacent leks. The maximum number of males sighted during all the counts at a given lek was considered to be the bird numbers. Ranges reflect inaccuracies in assessing numbers due to conditions in the field (presence of vegetation decreasing visibility), the birds' activity and movements within and between leks. To determine the changes in breeding population, the results of the 2011-2014 surveys were compared with those obtained in 2002 (Cichocki 2008). To ensure effective survey coverage, local birdwatchers were communicated in order to verify the location of known leks or the emergence of new ones. Both
Fig. 1 Location of study area (solid line country border, dashed line the Orawa region, circles location of leks of the black grouse Tetrao tetrix; grey and white colouration reflects the relief, indicating low and high altitudes, respectively)

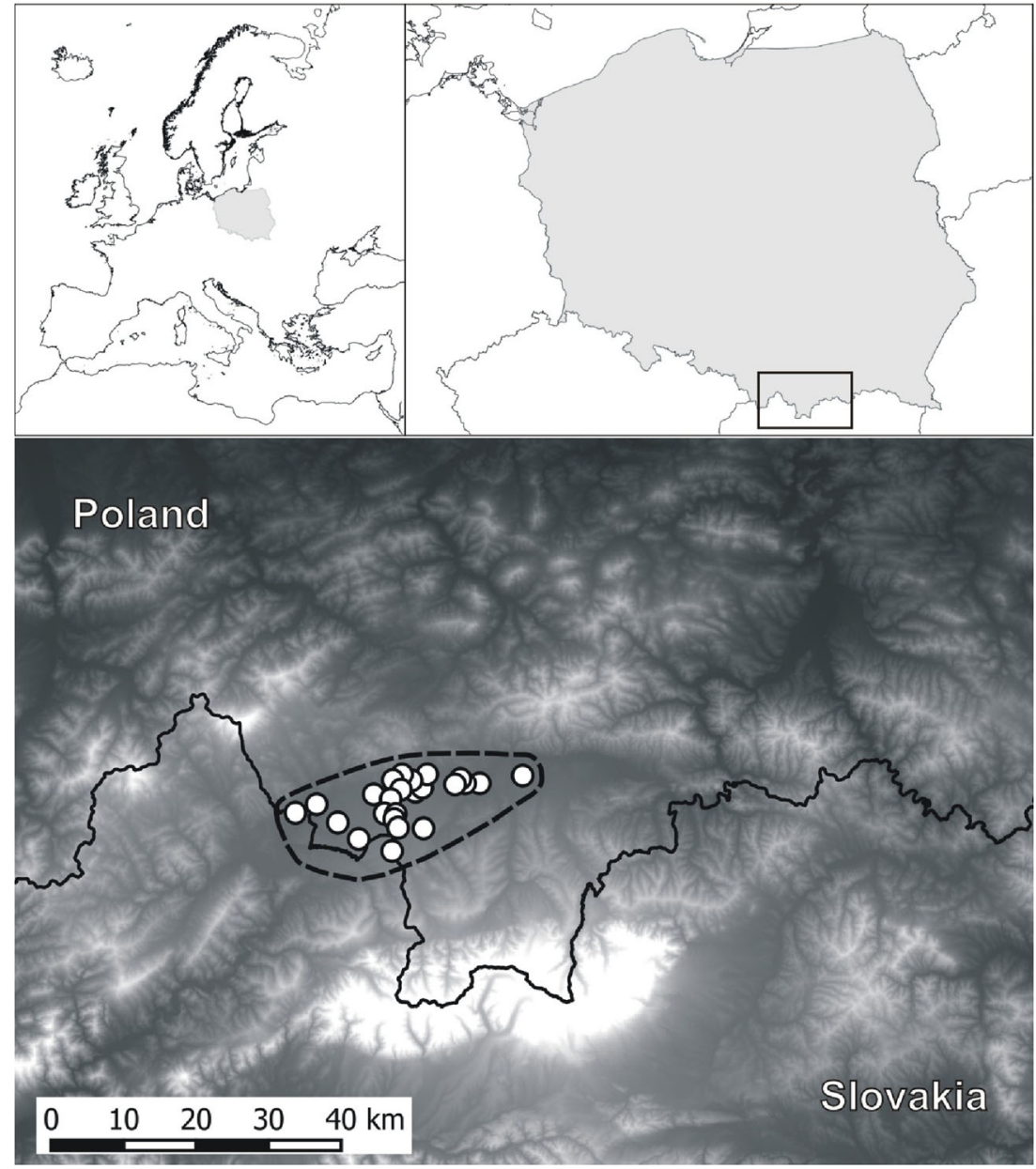


surveys were conducted in the same area, covered all suitable habitats and provided information on number of displaying males at all known leks.

In addition, areas that black grouse inhabited during the non-breeding period were surveyed from January to March 2011. In particular, the focus was on previously known areas of species occurrence (Ciach et al. 2006, 2010; Cichocki 2008). To determine the changes in non-breeding flock sizes, the results of the 2011 survey were compared with those obtained in 2002-2005 (Ciach et al. 2010). In both periods, surveys were conducted during winter, when permanent snow cover was present. Observers moved on transects running through habitats of black grouse and searched for flocks with binoculars and spotting scopes. A total of 51 and 21 man-days were devoted for flock searching in 2002-2005 and 2011, respectively.

To evaluate the impact of peat bog size on the process of disappearance of leks, the area (in ha) of the peat bog located in the nearest distance to each of the leks was calculated (based on Łajczak 2009). Two groups of leks (1) active and (2) abandoned in 2014 were distinguished. The total area occupied by the population $\left(\mathrm{km}^{2}\right)$ was calculated as a maximum convex polygon based on the location of the most widely separated active leks in a given year. The nearest neighbour distance (NND) between leks was calculated as the arithmetic mean of all the distances between the centres of the two nearest active leks $(\mathrm{m})$ in a given year. Both, the differences in flock sizes during the non-breeding period and the differences in peat bog area between active and abandoned leks were analysed using the Mann-Whitney $U$ test. One-way ANOVA was used to analyse the differences in NND between periods.

\section{Results}

In 2011, nearly half of the known leks disappeared altogether (11 out of 24), while the remaining active leks were used by a total of 41-45 males (Online resources: Table 1, Fig. 2). Single females were sighted at two leks, and two females at two other leks. This indicates that the number of lekking males declined by $70 \%$ since 2002 . In 2012, the active leks were used by $26-33$ males. Single females were found at only two active leks. In 2013, there were at least 17 lekking males. By 2014 , more than half of the known leks have been abandoned (13 out of 24), and the remaining active leks were being used by a total of 29-36 lekking males (Online resources: Table 1, Fig. 2). At the same time, 19 females were sighted at eight active leks (range 1-4). In consequences, the number of lekking males declined by $76 \%$ between 2002 and 2014 .

The persistence of leks was associated with the size of the nearest peat bog. Median area of the nearest peat bog was 86.8 ha (quartile range $56.3-116.3, N=13$ ) at leks, which were abandoned. Median area of the nearest peat bog on active leks was 272.5 ha (quartile range 116.3-660.0, $N=11$ ) and differed significantly from deserted leks $\left(Z_{\mathrm{c}}=2.68 ; p=0.007\right)$. The median size of wintering flocks of black grouse in 2002-2005 was six birds, whereas in winter 2011, it was barely two (Online resources: Fig. 3). Even though there were no large flocks of birds in the second study period, this difference was not statistically significant $\left(Z_{\mathrm{c}}=1.69 ; p=0.09\right)$. The surface area used by black grouse more than halved within 10 years. In 2002-2005, it was $187.3 \mathrm{~km}^{2}$, in 2011, it was $128.9 \mathrm{~km}^{2}$, but in 2014 , it was only $71.5 \mathrm{~km}^{2}$. Along with the reduction in surface area used by the black grouse, there was no change in NND between active leks (one-way ANOVA $F_{(2,45)}=1.27, p=$ 0.291 ). In 2002-2005, the mean NND between active leks was $2092.6 \mathrm{~m}( \pm 1283.7 \mathrm{SD}$, range $722.5-6012.5 \mathrm{~m}, N=24)$, in 2011 , it was $2787.8 \mathrm{~m}( \pm 1721.7 \mathrm{SD}$, range $1072.7-$ $5996.0 \mathrm{~m}, N=13)$, and in 2014 , it was $2092.0 \mathrm{~m}( \pm 890.3$ $\mathrm{SD}$, range $1072.7-4076.5 \mathrm{~m}, N=11)$.

\section{Discussion}

The results of the present work testify to the very rapid decrease in numbers of black grouse in the Orawa region in recent years. Data from both the breeding and the nonbreeding periods show that the black grouse population inhabiting the Orawa region, only recently assessed as being the largest and most numerous in Poland (Tomiałojć and Stawarczyk 2003), is contracting dramatically. In 2002, a total of 146-152 male black grouse were present at all the leks (Cichocki 2008), whereas in 2004-2007, there were 110 130 males (Cichocki 2010). According to the results of the present work, there have been scarcely 30-40 males in recent years. The threefold drop in black grouse numbers in just a few years indicates that local populations could be disappearing at an alarming rate. The population on the Slovakian part of the Orawa Basin, considered until recently as a one of the main population in the country (Danko et al. 2002), has disappeared totally in recent years (D. Karaska - pers. comm.). The black grouse's decline in this part of Poland and Slovakia parallels that recorded in almost the whole of this species' European range of distribution (Baines and Hudson 1995; Ludwig et al. 2008; Sim et al. 2008). The reasons for this decline in black grouse numbers in the studied population are not fully understood. It is highly likely that the factors, recognised earlier in other European populations of black grouse that subsequently declined in size or became extinct, are responsible for the decline in the Orawa region as well.

Key to the black grouse is the presence of raised bogs, which together with heathland, are the preferred habitat types (Baines 1994; Starling-Westerberg 2001). Results of present paper confirm that persistence of leks was associated with the 
area of the nearest peat bog. Arenas located close to small peat bogs had been abandoned, while those located close to bigger ones were still active. Peat bogs offer food resources in the form of leaves, shoots, buds and fruits of shrubs and trees (Storch 2007). They are very sensitive to drops in water level, changes in the water's chemistry, and also to mechanical damage and peat digging. As a result of human activities, the surface area of peat bogs in the Orawa region has shrunk from 3500 to 1300 ha in the past centuries (Lajczak 2013), leading to the direct habitat loss and the degradation (drainage) of remaining peat bogs. Waterlogged habitats are not frequented so much by predators; this is probably due to the low densities there of small rodents, which are the staple diet of both red foxes and some raptors. However, dried out areas are probably easier for terrestrial predators like the red fox to penetrate.

The black grouse avoids dense woodland and is defined as a species of early successional habitats (Dmoch 2005; Storch 2007). The maturation of tree stands may be one of the causes of the species' decline (Pearce-Higgins et al. 2007). However, black grouse can inhabit open marshy coniferous woodland, disaster areas in forests and early-stage tree stands, i.e. coppices until they become close-canopied (Storch 2007). The maturation of tree stands and the closing of their canopies may be one of the reasons for the withdrawal of the species from some of the terrain it used to inhabit, although in the population under study here, early successional habitats are present over practically the whole of the Orawa region: this is because a significant part of the once ubiquitous meadows and pastures here has been abandoned.

Black grouse avoid built-up areas and all kinds of roads (Dmoch 2005; Patthey et al. 2012). The adverse effects of transport routes are due to the fragmentation of habitats, and also to the greater level of disturbance resulting from the mere presence of people. In recent years, the Orawa region has witnessed ongoing urbanisation; the new buildings are widely scattered. Moreover, built-up areas are attractive to predators, both those associated with humans, like cats and dogs, as well as those that avail themselves of the proximity of humans, such as urban foxes or ravens at rubbish dumps. It has become standard practice to disperse anti-rabies vaccines in the countryside, and this has led to an increase in the numbers of predators, mainly red foxes. Predator pressure may well be one of the main threats to the black grouse population (Summers et al. 2004).

The decline in the black grouse population is most likely due to reduced reproductive success. The reasons for this may include pressure on the part of predators, but also changes to the climate and climatic extremes (Summers et al. 2004; Selås et al. 2011). In recent years, southern Poland has regularly experienced considerable cooling in May and June, accompanied by rainfall. Such inclement weather, which can last from a few days up to a few weeks, coincides with the incubation of eggs and the raising of the young. Low temperatures and rainfall can give rise to hypothermia in the young birds, which can in turn reduce the survival rate. In addition, berry-bearing shrubs may produce less fruits, their chemical content may change in disfavour of the black grouse, and the caterpillars feeding on the shrubs, the staple food for young black grouse, may become fewer in number (Selås et al. 2011). In consequence, this leads to the reduction in forage quality and foraging efficiency. Due to increase of time devoted for foraging, reduction of vigilance and prolonged exposure of individuals on the predators during the search for high-quality food may lead to increase in mortality.

To summarise, the population of black grouse, until recently regarded as the most numerous in Poland, has regressed to an alarming extent in the last ten years. The reasons for this are likely that a whole complex of factors acts cumulatively and is responsible for the drop in numbers. If appropriate conservation measures fail to be undertaken, we can expect a further decline in the population and thus possibly of its extinction within a few years. The results of this study show that even relatively large but isolated populations can become extinct within a short period of time. The functioning of black grouse in a metapopulation in which movements are limited may be fraught with risk in the longer term. Threats to populations should be taken into consideration when planning conservation and management actions for the entire range of the species.

Acknowledgments I am grateful to M Albrycht, R Bobrek, L Bujoczek, M Bujoczek, K Bul, A Chwierut, G Cierlik, S Czyżowicz, A Flis, A Fröhlich, M Gubernat, P Hotała, K Kędra, A Krogulec, W Król, D Kurlej, B Kwarciany, J Marciniak, W Mrowiec, W Nieścior, A Pepkowska-Król, M Stefanik, M Strzałka, M Trybała, T Wilk, S Woźniak and A Zięcik for their help during the fieldwork. In 2011, this study was financed by the Ministry of Science and Higher Education (Iuventus Plus IP2010005570). In 2014, the fieldwork was supported by the Swiss Contribution program.

Ethical statement The study was performed in accordance with the law regulations in Poland.

Open Access This article is distributed under the terms of the Creative Commons Attribution 4.0 International License (http:// creativecommons.org/licenses/by/4.0/), which permits unrestricted use, distribution, and reproduction in any medium, provided you give appropriate credit to the original author(s) and the source, provide a link to the Creative Commons license, and indicate if changes were made.

\section{References}

Baines D (1994) Seasonal differences in habitat selection by black grouse Tetrao tetrix in the northern Pennines, England. Ibis 136:39-43

Baines D, Hudson PJ (1995) The decline of black grouse in Scotland and northern England. Bird Study 42:122-131 
Ciach M, Wikar D, Bylicka M (2006) Birds community of open habitats of Kotlina Orawsko-Nowotarska valley in non-breeding season. Berkut 15:55-65

Ciach M, Wikar D, Bylicka M, Bylicka M (2010) Flocking behaviour and sexual segregation in black grouse Tetrao tetrix during the nonbreeding period. Zool Stud 49:453-460

Cichocki W (2008) Rozmieszczenie tokowisk cietrzewia w Kotlinie Orawsko-Nowotarskiej. In: Haze M (ed) Ochrona Kuraków Leśnych. Centrum Informacyjne Lasów Państwowych, Warszawa, pp 34-38

Cichocki W (2010) Torfowiska Orawsko-Nowotarskie. In: Wilk T, Jujka M, Krogulec J, Chylarecki P (eds) Ostoje ptaków o znaczeniu międzynarodowym w Polsce. OTOP, Marki, pp 419-420

Danko Š, Darolová A, Krištín A (2002) Birds distribution in Slovakia. VEDA, Bratislava

Dmoch A (2005) Ekologiczne podstawy ochrony cietrzewia (Tetrao tetrix L., 1758) w Kotlinie Biebrzańskiej. PhD Thesis, SGGW Warszawa

Hagemeijer EJM, Blair MJ (eds) (1997) The EBCC Atlas of European Breeding Birds: their distribution and abundance. T \& AD Poyser, London

Höglund J, Larsson JK, Jansman HAH, Segelbacher G (2007) Genetic variability in European black grouse (Tetrao tetrix). Conserv Genet 8:239-243

Kamieniarz R (1997) Changes in distribution and population size of black grouse in Poland during 1982-83 and 1993-94. J Wildl Res 2:82-85

Kamieniarz R (2008) Zmiany występowania cietrzewia w Polsce miedzy latami 1993-94 i 2006-2007. In: Haze M (ed) Ochrona Kuraków Leśnych. Centrum Informacyjne Lasów Państwowych, Warszawa, pp 38-46

Łajczak A (2009) Development conditions and distribution of peat bogs in the Orava-Nowy Targ Basin. Przegl Geol 57:694-702
Łajczak A (2013) Reduction of the extent of peat deposits and their water retention capacity in the Orava-Nowy Targ Basin and Bieszczady Mts. due to human activity. Przegl Geol 61:532-540

Ludwig T, Storch I, Wübbenhorst J (2008) How the black grouse was lost: historic reconstruction of its status and distribution in Lower Saxony (Germany). J Ornithol 149:587-596

Patthey P, Signorell N, Rotelli L, Arlettaz R (2012) Vegetation structural and compositional heterogeneity as a key feature in Alpine black grouse microhabitat selection: conservation management implications. Eur J Wildl Res 58:59-70

Pearce-Higgins JW, Grant MC, Robinson MC, Haysom SL (2007) The role of forest maturation in causing the decline of black grouse Tetrao tetrix. Ibis 149:143-155

SDF Standard Data Form (2012) Special Protection Area SKCHVU008 Horná Orava. http://natura2000.eea.europa.eu/Natura2000/SDF. aspx? site=SKCHVU008

Selås V, Sonerud GA, Framstad E, Kålås JA, Kobro S, Pedersen HB, Spidsø TK, Wiig Ø (2011) Climate change in Norway: warm summers limit grouse reproduction. Popul Ecol 53:361-371

Sim IMW, Eaton MA, Setchfield RP, Warren P, Lindley P (2008) Abundance of male black grouse Tetrao tetrix in Britain in 2005 , and change since 1995-96. Bird Study 55:304-313

Starling-Westerberg A (2001) The habitat use and diet of black grouse Tetrao tetrix in the Pennine hills of northern England. Bird Study 48:76-89

Storch I (2007) Grouse. Status Survey and Conservation Action Plan 2008-2010, IUCN, Gland, Switzerland and Cambridge. UK and World Pheasant Association, Fordingbridge

Summers RW, Green RE, Proctor R, Dugan D, Lambie D, Moncrieff R, Moss R, Baines D (2004) An experimental study of the effects of predation on the breeding productivity of capercaillie and black grouse. J Appl Ecol 41:513-525

Tomiałojć L, Stawarczyk T (2003) Awifauna Polski. Rozmieszczenie, liczebność i zmiany. PTPP ,pro Natura”. Wrocław 